\title{
JUM'AT BERSIH
}

ROSTINA

9173770410190

sritinawahuyuni01@gmail.com

1. Bentuk Kegiatan

$>$ Membersihkan masjid setiap hari jum'at.

2. Lokasi

> Mesjid Babussalam, dusun Bisanti desa Bontocini.

3. Hari/Tanggal dan Waktu

> Jum'at, 9 oktober 2020 pukul 07:30 - Jum'at 16 oktober selesai.

4. Peserta yang Dilibatkan

$>$ Mahasiswa KKLP Yapti Jeneponto.

5. Alasan Diadakannya

> Alasan diadakannya adalah karena melihat keadaan masjid yang terlihat kotor mengingat akan di laksanakan sholat jum;at maka kami para Mahasiswa berinisiatif membersihkan Masjid tersebut.

6. Tujuan dan Manfaat

> Tujuan dan Manfaatnya adalah untuk membersihkan Masjid agar supaya Masyarakat Desa Bontocini dapat beribadah dengan nyaman.

7. Deskripsi Kegiatan

> Kegiatan membersihkan Masjid ini dilakukan pada pagi hari , sebelum dilaksanakannya sholat jum'at Masjid sudah dalam keadaan bersih. 